\title{
OVERVIEW OF BSI DIGITALIZATION IN CREATING A HEALTHY COMPETITIVE MARKET BY OPTIMIZING EXISTING STATE-OWNED BANK CUSTOMERS
}

\author{
Alivia Fitriani Hilmi ${ }^{1}$, Chetrine Alya Rinaima ${ }^{2}$, Isa Zulfarida Arini ${ }^{3}$ \\ 1,2,3 Faculty of Economics and Islamic Business, Sunan Ampel State Islamic University, \\ Surabaya \\ Email: aliviahilmy@gmail.com
}

\begin{abstract}
Indonesia has great potential for the development of the Islamic banking industry. However, the reality shows that this potential increase runs contrary to the development of Islamic banking. The concept of policies that have been set by the government has not been able to persuade the public to use Islamic banking. Therefore, the government implemented the latest policy, namely the merger of Islamic banks by providing one mobile banking. Where there is a merger of Islamic banks accompanied by digitalization, it automatically makes Indonesian Islamic banks a holding bank with larger capital, practical, efficient and easily recognizable. The merger of Islamic banks will strengthen the Islamic banking sector which is predicted to be able to move the real sector and have the highest assets. with the existing potential, the authors conducted research on the development of sharia bank customers by optimizing the digitalization of BSI with the potential for existing BUMN bank customers who have not used sharia services with a healthy competitive market. The research method used is SWOT analysis, as well as quantitative descriptive and simple linear regression T-test with observation data random sample. SWOT matrix analyzed the results also indicate one or mergers quadrant Islamic banks must maintain an aggressive strategy by leveraging the dominance of one bank BUMN. Besides existing customers, the result of quantitative descriptive analysis based on the Likert scale and intervalscale, $72 \%$ of 60 respondents agreed to the item - a questionnaire item that refers to the creation of a healthy competitive market with the existence of BSI digital banking. From the results of the T-test, it shows that there is an influence between the digitalization of banking mergers of Islamic banks on the optimization of existing customers of stateowned banks.
\end{abstract}

Keyword: Bank Merger, Bank Sharia Indonesia, existing customers, competitive market 


\section{Intro duction}

The latest data in 2020, the number of Muslim population in Indonesia reached 229 million people from around 273,523.621 million total Indonesian population. Where in the previous year, 2019 of the 207 million Muslim population at that time, based on the latest OJK data in 2019, it was shown that only 35.9 million Muslim residents had sharia banking accounts. The Financial Services Authority also detailed the number of sharia account holders, namely 5.62 million accounts in the financing provided sector and 30.28 million accounts in the DPK sector. Thus, in 2019 there were still 172 million Muslim residents who did not have an account and used Islamic banking services, while this number could also continue to grow given the development of Indonesia's Muslim population which increased significantly in the following year.

This reality is certainly an irony for the title of the state of Indonesia as the country with the largest Muslim population, where Indonesia should be the center and reference for the world in terms of developing Islamic finance (Tho'in 2019). This feasibility assessment is also supported by several potentials that will support Indonesia's position as a center for the development of Islamic finance, including: (i) large potential of sharia customers; (ii) economic growth reaching $6.0 \%-6.5 \%$ or at a relatively high level; (iii) the potential for increased investor interest in finance which also includes Islamic finance due to an increase in Indonesia's sovereign credit rating; (iv) underlying transactions in the Islamic finance industry will be supported by Indonesia's rich and abundant geography (Alamsyah 2012)

In order to optimize banking and sharia financial inclusion, the government creates policies that integrate sharia financial service products with conventional financial services. Where the purpose of this integration is to facilitate the introduction of Islamic financial products through the reputation of conventional state-owned banks that first serve the Indonesian people. But in fact, the tactics that have been designed by the government are less effective in increasing the public's persuasion to be able to access Islamic financial services, and have not yet reached the expected projection target. Until, on February 1, 2021, Bank Sharia Indonesia (BSI) was inaugurated, which was the result of the merger of 3 state Islamic banks with good track records, namely PT Bank Sharia Mandiri Tbk, PT Bank BNI Sharia Tbk, and PT Bank BRI Sharia Tbk. The merger of sharia banking was also followed by the provision of BSI digital banking where even digital banking customers from the previous 3 sharia banks could automatically activate the newly owned BSI mobile banking. This is a double step forward for Islamic banking in Indonesia. This decision is also in accordance with the statement according to the Global Islamic Economic Report, where the solution as well as a business opportunity that must be implemented is to create banking mobile banking Islamic. This is because Islamic banking can unlock substantial growth and profitability through sector digitization and 2020 
focus opportunities on the implications of using financial technology in banking (Thomson Reuters 2018).

This merger step has shown significant results in the field where in less than a year since it was inaugurated, Bank Sharia Indonesia has recorded a $97.4 \%$ growth in mobile banking or as many as 46.4 million transactions in 2021. However, this merger step can significantly At first glance, it is considered to be turning off other Islamic banking. Therefore, this study will review that the existence of Indonesian Islamic banks actually creates a healthy competitive market competition without turning off other Islamic banking. In this study, it will be tested by quantitative descriptive observation and also explained how precisely the Indonesian Islamic Bank with digital banking can create a healthy competitive market.

In addition, this study also includes a T-test regarding the optimization of the introduction of Islamic bank products to customers existing of state-owned banks. These two separate studies on these two different variables are intended so that readers and researchers can present detailed research on each variable. Previously, a SWOT analysis was also carried out on the merger policy of government-owned sharia banks in order to provide an overview of the efficiency of the sharia bank merger policy. SWOT analysis is also presented to be able to provide certainty of strategies that need to be achieved and carried out so that the authors can propose innovation variables that will be tested further. In short, the purpose of this study is to present the efficiency level of bank merger policies and the next steps that can be taken according to the results of the proposed research to further maximize the inclusion of Islamic banking finance.

\section{Literature Review}

\section{Merger bank}

Bank merger is a decision to achieve strategic steps in order to improve bank performance more efficiently. The definition of a merger is the merging of two or more companies into an existing company, which means that the merger involves two parties, namely the company accepting the merger and the merging company. The implementation of the merger policy is motivated by many factors, including improving work efficiency, maintaining income stability, controlling market share, increasing prestige and so on. The implementation of this merger strategy makes a bank have a new, stronger entity and the goal will be achieved faster than having to start from scratch. The main purpose of banks conducting mergers is to improve bank performance and increase profits.

\section{BSI Digitalization}

The application of digital technology leads to increased productivity and efficiency of companies to compete. Digital banking allows customers to obtain 
banking services independently without having to go to the bank by paying attention to all security aspects. According to the Financial Services Authority (OJK), digital banking services allow bank customers to obtain information, communicate, register, open accounts, banking transactions, and close accounts, including obtaining other information and transactions outside of banking products, including financial advice, investment, electronic-based trading system transactions (e-commerce), and other needs of the Bank's customers. Digital services are also implemented by Bank Sharia Indonesia by using a mobile banking application after the merger with the name BSI Mobile. The BSI mobile application can be directly updated by application users of BRISharia Bank, Mandiri Sharia Bank, and BNI Sharia Bank. Customer accounts will be automatically migrated from each previous bank to the new BSI account.

\section{Existing Customers}

According to (Kasmir 2008) customers are consumers who buy or use products sold or offered by banks. Existing customers are customers who use products at certain banks. In this case, the existing customers of state-owned banks means customers who use state-owned bank products as an option in banking transactions.

\section{Competitive Market}

A competitive market is a market that has a very high level of competition. There are a number of potential buyers and sellers in this market. Competitive markets have a different level of competition from non-competitive markets where producers have control over the price of the products sold. The characteristics possessed by a competitive market include many companies in the market, this trait causes companies to have no power to change prices.

Framework

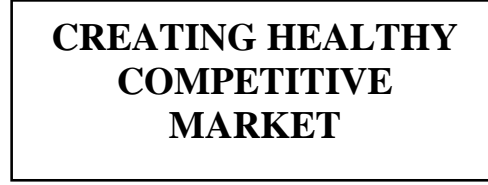

DOMINATION OF EXSISTING

CUSTOMER BANK

STATE-OWNED

BUSINESS ENTITY

Dependent variable
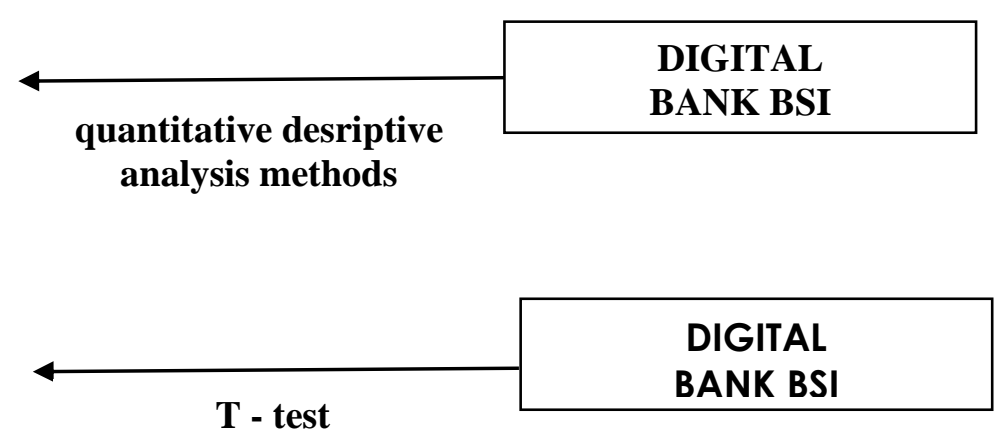

Independent Variable

\section{Hypothesis Development}

1. The Influence of Digital banking BSI on Creating Healthy Competitive Market According the observation of secondary data on the creation of a competitive market of Islamic banking through the presence of BSI mobile banking is also 
based on some of the following OJK Statistics on the comparison of other Islamic commercial banks since BSI was inaugurated in February 2021(Keuangan 1967) and (Ojk.go.id 2021) :

Table 1. OJK Statistics on the comparison of other Islamic commercial banks

\begin{tabular}{|l|l|c|}
\hline \multicolumn{1}{|c|}{$\begin{array}{c}\text { Name of Islamic } \\
\text { commercial bank }\end{array}$} & \multicolumn{1}{|c|}{$\begin{array}{c}\text { Number of branches } \\
\text { /February 2021 }\end{array}$} & $\begin{array}{c}\text { Number of branches } \\
\text { /April 2021 }\end{array}$ \\
\hline BTPN Sharia & 14 branches & 15 branches \\
\hline Bank Muamalat & 131 branches & 131 branches \\
\hline Bank Mega Sharia & 29 branches & 29 branches \\
\hline
\end{tabular}

In the Islamic banking statistics, it is known that Islamic commercial banks other than BSI can still develop competitive power by maintaining the number and even increasing the number of branch offices after BSI is present. In the creation of this competitive market in addition to being supported by theory, there is secondary data on public opinion about the use of other banking from previously owned banking. As a complement, according to Porter's theory, there are several factors that affect a product can be competent, namely; The conditions of resources (natural resources, human resources and resources of science and technology), conditions of demand (domestic demand and foreign demand), and the last factor is competition and strategy (Alexander and Nadapdap 2019).

H1: BSI digital banking can create a competitive market for other Islamic general banks

2. The Influence of Digital banking BSI on Domination of Existing Customer Bank State-Owned Business Entity

Respondents aged 17-50 years or the range where the community limit can register banking customers while 50 years is where according to Permenaker No. 02/1995 mentioned the retirement age is set at 55 years("Jdih Kemnaker" n.d.), and as an average for those who work without the auspices of an official company, then we decided on a sample range of up to 50 years assuming the limit of working and actively using banking services. Existing customer is a variable that can also be proven from assumptions and secondary data. Further to that, the measurement of existing customers is also done by analyzing the objectivity of state-owned bank customers against 8 questionnaire items that have passed the validation test, where in this questionnaire there are several points that can be an indication of existing customers as follows:

1. customer tendency

2. Have easy access

3. Desire to use a new product 
4. Interest in the product

5. a sense of security towards the managing holders

And 8 questionnaire items that have passed the validation test are:

Table 2. Recapitulation of questionnaire items

\begin{tabular}{|c|c|c|c|}
\hline Questionnaire Items & $\begin{array}{c}\text { Agrees Interval } \\
\text { (in \%) }\end{array}$ & $\begin{array}{c}\text { Neutral } \\
\text { intervals } \\
\text { (in \%) }\end{array}$ & $\begin{array}{c}\text { Disagrees } \\
\text { Interval } \\
\text { (in \%) }\end{array}$ \\
\hline $\begin{array}{l}\text { Customer tendency } \\
\text { towards state-owned } \\
\text { banks due to the } \\
\text { number of branches }\end{array}$ & $94.12 \%$ & $2.94 \%$ & $2.94 \%$ \\
\hline $\begin{array}{l}\text { Reason that access is } \\
\text { easy: ATMs are } \\
\text { spread in many } \\
\text { places and the use of } \\
\text { cards in various } \\
\text { needs }\end{array}$ & $99.06 \%$ & $0 \%$ & $2.94 \%$ \\
\hline $\begin{array}{l}\text { The reason } \\
\text { customers use state- } \\
\text { owned banks is also } \\
\text { because of their use } \\
\text { as mandatory } \\
\text { payment access. }\end{array}$ & $89.23 \%$ & $8.82 \%$ & $2.94 \%$ \\
\hline $\begin{array}{l}\text { The desire to } \\
\text { immediately use } \\
\text { mobile banking at } \\
\text { owned banks }\end{array}$ & $73.53 \%$ & $17.65 \%$ & $8.82 \%$ \\
\hline $\begin{array}{l}\text { Reluctance to use } \\
\text { state-owned banks } \\
\text { due to better quality } \\
\text { of private banks }\end{array}$ & $32.35 \%$ & $23.53 \%$ & $44.12 \%$ \\
\hline $\begin{array}{l}\text { Interest in new } \\
\text { products launched } \\
\text { by state-owned } \\
\text { banks }\end{array}$ & $50 \%$ & $41.18 \%$ & $8.82 \%$ \\
\hline $\begin{array}{l}\text { Customer loyalty } \\
\text { when there is a } \\
\text { change in the }\end{array}$ & $58.83 \%$ & $35.29 \%$ & $5.88 \%$ \\
\hline
\end{tabular}




\begin{tabular}{|l|l|l|l|}
\hline $\begin{array}{l}\text { operating rules of } \\
\text { state-owned banks }\end{array}$ & & \\
\hline $\begin{array}{l}\text { A sense of security } \\
\text { because state-owned } \\
\text { banks are managed } \\
\text { under the auspices of } \\
\text { the government }\end{array}$ & $73.53 \%$ & $23.53 \%$ & $2.94 \%$ \\
\hline
\end{tabular}

H2: BSI digital banking can be optimized for its use by utilizing existing customers of state-owned banks

\section{Research Methods}

The research method used is quantitative which is research using a quantitative data approach or a type of data that can be quantified and processed with statistics. The study involved 60 respondents. The sampling technique in this study used random observations of samples in respondents aged 17 years - 50 years. In this study the data collection method uses the technique of spreading the questionnaire. Questionnaire is a series of questions related to a particular topic given to a group of individuals with a questionnaire to obtain data. Questionnaire is distributed to people who use the services of state-owned banks and non-state-owned banks with restrictions, including Indonesian citizens (WNI) with an age range of 17-50 years. The questionnaire consists of several statements regarding the reasons for using state-owned / non-state-owned banks and the excess shortage of state-owned / non-stateowned banks.

\section{Data Analysis Method}

This study uses a method where in this case there are several tests or analyzes used. First, the SWOT analysis for the merger policy of sharia banking. SWOT analysis is a technique in determining the strategy of a company or business by considering the results of the evaluation of Strengths, Weaknesses, Opportunities, and Threats both on current activities or on new planning activities (UTAMI 2019). The final result of this SWOT analysis is a strategy that must be done by looking at the results of the SWOT matrix.

Second, quantitative descriptive analysis method. This second method is carried out on a descriptive hypothesis which states that digital banking as a result of the merger of Islamic banks can create a healthy competitive market. The data collection method used is aobservation random sample on respondents aged 17 years - 50 years using a questionnaire that uses a Likert scale. The Likert scale is a scale invented by Rensis Likert and is commonly used as a survey questionnaire scale where respondents can indicate how much agreement they have on the questions provided (Kho 2018). The following are the levels of agreement and scores on a Likert scale: 

a. Strongly agree $=5$
b. Agree $=4$
c. Neutral =3
d. Disagree $=2$
e. Strongly disagree $\quad=1$

Third, the next analysis is used for the second variable, namely optimizing the introduction of Islamic banking products through existing customers of state-owned banks. The research method used in this variable is the T-test of data from simple linear regression analysis. The hypothesis in this T-test is the effect of digital banking mergers of Islamic banks on optimizing the introduction of Islamic banking products through existing customers of stateowned banks. Thus, it can be concluded that the variable $x$ is the digital banking merger of Islamic banks and the variable y used is the optimization of the introduction of Islamic banking products through existing customers of stateowned banks. This T-test uses Eviews software. The T-test is one of the statistical hypothesis tests that is tested to determine the strength of the sample to be able to generalize a population (Santoso 2019). There are several provisions in this t-test, several things can be concluded as follows: Analysis criteria, analysis provisions and analysis results and conclusions. The final result of the t-test hypothesis analysis is the positive or negative effect of variable $x$ on variable $y$. The data collection method in this t-test analysis is a random sample observation with a Likert scale such as the data collection technique in the second research method above.

\section{Result and Discussions}

\section{SWOT analysis}

The SWOT analysis is the first analysis that is carried out to determine the evaluation of the strategy first. Then, a new hypothesis can be determined that can support the achievement through the evaluation of the previous strategy. The analysis here displays the IFAS results for processing internal elements, namely Strengths and Weaknesses and EFAS results as a form of processing the results of scoring external elements, namely Opportunities and Threats. The results of the SWOT analysis regarding government policies in integrating 3 state-owned Islamic banking are as follows:

IFAS

$$
\begin{aligned}
& =x=a-b \\
& =3-1.9 \\
& =1.1
\end{aligned}
$$

EFAS

$$
\begin{gathered}
=y=c-d \\
=3.4-2.4
\end{gathered}
$$




$$
=1
$$

Then the result is $(X, Y)=(1,1,1)$. And to be able to map out the evaluation of the strategy for the merger of state-owned Islamic banks, it is necessary to determine the place of the quadrant in the SWOT matrix. Here are the results of the SWOT matrix:

Picture 1 The Result of SWOT Matrix

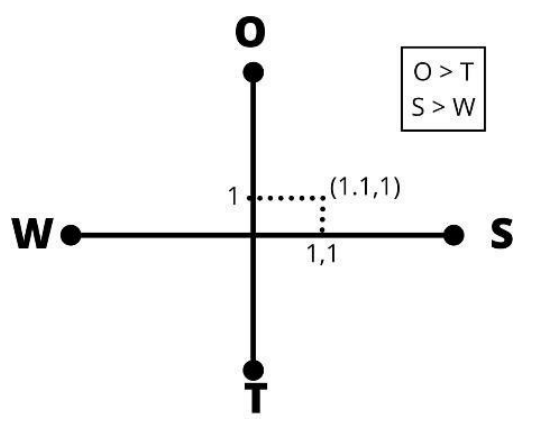

In the matrix above, the evaluation of the strategy falls in quadrant 1 . Thus, the strategy carried out is appropriate or on the track but to maintain competence, the strategy must be aggressive or growth-oriented strategy which, according to Astuti and Ratnawati, can be identified because it has great opportunities and can maximize the opportunities they have. In other words, the merger of Islamic banks has many opportunities as a top leader in the growth and development of Islamic finance in Indonesia. And as a strategy, Bank Sharia Indonesia must be able to maximize the opportunities it has, one of which is the existence of customers who have interest and trust (existing) in state-owned banks, as well as opportunities for BSI as the creator of a competitive Islamic banking market in innovating and serving the community.

\section{Reliability Test}

Descriptive quantitative analysis of 60 respondents obtained through random sampling of Indonesian population aged 17-50 years, obtained total results and matching two questionnaire items using a Likert scale with the following conditions:

Number of respondents: 60 people

Maximum score that can be obtained: $5 \times 60=300$

Minimum score that can be obtained: $1 \times 60=60$

$$
\begin{gathered}
\text { data interval }=\frac{100}{\text { number of answers }} \times 100 \% \\
\text { data interval }=\frac{100}{5} \times 100 \% \\
=20
\end{gathered}
$$

From the above calculation, the assessment interval is obtained as follows:

- Number $0 \%$ - $19.99 \%$ = Strongly disagree

- Number 20\% - 39.99\% = Disagree

- Number $40 \%$ - 59.99\% = Neutral

- Number $60 \%$ - 79.99\% = Agree 
- Number $80 \%-100 \%$ = Strongly agree

Question: the reason dislike state-owned banks is because the existence of private banks that have better services

Table 3. Recapitulation of questionnaire items 1

\begin{tabular}{llll}
\hline Description & Score & $\begin{array}{l}\text { Numbers of } \\
\text { Respondents }\end{array}$ & Total Score
\end{tabular}

\begin{tabular}{llll}
\hline Strongly agree & 5 & 2 & 10 \\
\hline Agree & 4 & 3 & 12 \\
\hline Neutral & 3 & 5 & 15 \\
\hline Disagree & 2 & 23 & 46 \\
\hline Strongly disagree & 1 & 27 & 27 \\
\hline \multicolumn{1}{c}{ TOTAL } & & $\mathbf{6 0}$ & $\mathbf{1 1 0}$ \\
\hline
\end{tabular}

$$
\begin{gathered}
\text { Result }=\frac{\text { total score }}{\text { maximum score }} \times 100 \% \\
\frac{110}{300} \times 100 \%=36,7 \%
\end{gathered}
$$

The results above show that the calculation results are in the index number $36.7 \%$. This shows that customers do not agree with the statement that state-owned banks are less attractive because of private banks with better services.

Question: If the state-owned bank that the respondent uses has a new service, they want to immediately use the new service.

Table 4. Recapitulation of questionnaire items 2

\begin{tabular}{lccc}
\hline Description & Score & $\begin{array}{l}\text { Numbers of } \\
\text { Respondents }\end{array}$ & Total Score \\
\hline Strongly agree & 5 & 11 & 55 \\
\hline Agree & 4 & 19 & 76 \\
\hline Neutral & 3 & 25 & 75 \\
\hline Disagree & 2 & 5 & 10 \\
\hline Strongly disagree & 1 & 0 & 0 \\
\hline \multicolumn{1}{r}{ TOTAL } & & $\mathbf{6 0}$ & $\mathbf{2 1 6}$ \\
\hline
\end{tabular}

$$
\text { Result }=\frac{\text { total score }}{\text { maximum score }} \times 100 \%
$$




$$
\frac{216}{300} \times 100 \%=72 \%
$$

The survey results show an index number of $72 \%$ which is included in the "agree" interval. This shows that existing customers of state-owned banks agree that if there are new services at state-owned banks, they are interested in using their services. In this case, the author concludes that the existing customers of stateowned banks will most likely use the services of Bank Sharia Indonesia which is the result of a merger of state-owned Islamic banks.

\section{T-test}

The $t$-test is one of the hypothesis tests, where the t-test is carried out to determine the effect of the digital banking merger of SOE Islamic banks on the optimization variable for the dominance of existing state-owned bank customers. Assessment can be done by assessing the comparison of T statistical results of linear regression processing through software with T table one tail or two tail. Another way of processing the t-test can also use the p-value or tsignificance compared to the tolerable significance level of $5 \%$ or 0.05 . The following is the processing of the T-Test:

Hypothesis: the effect of digital banking as a result of the merger of Islamic banks on the use of the dominance of existing customers of state-owned banks.

Table 5. Linear regression results using Eviews 9 software

Dependent

Variable: Y

Method: Least

Squares

Date: 09/21/21 Time: 05:05

Sample: 160

Included observations: 60

\begin{tabular}{|c|c|c|c|c|}
\hline $\begin{array}{c}\text { Varia } \\
\text { ble }\end{array}$ & $\begin{array}{r}\text { Coefficien } \\
\mathrm{t}\end{array}$ & Std. Error & $\begin{array}{l}\text { t- } \\
\text { Statistic }\end{array}$ & $\begin{array}{l}\text { Prob } \\
. \\
\end{array}$ \\
\hline $\mathrm{C}$ & 37.01082 & 23.63943 & $\begin{array}{l}1.56564 \\
0\end{array}$ & 0.1229 \\
\hline$X$ & 1.074155 & 0.188260 & $\begin{array}{l}5.70569 \\
8\end{array}$ & 0.0000 \\
\hline
\end{tabular}

R-squared $\quad 0.359505$ Mean dependent var 171.566 


\begin{tabular}{lclr}
\hline & & & 7 \\
$\begin{array}{l}\text { Adjusted R- } \\
\text { squared }\end{array}$ & 0.348462 & $\begin{array}{l}\text { S.D. } \\
\text { dependent var }\end{array}$ & 15.7042 \\
S.E. of regression & 12.67612 & $\begin{array}{l}\text { Akaike info } \\
\text { criterion }\end{array}$ & 7.95008 \\
& & Schwarz & 2 \\
Sum squared resid & 9319.669 & criterion & 8.01989 \\
& & Hannan-Quinn criter. & 7.97738 \\
Log likelihood & -236.5024 & 9 \\
& & & 1.85385 \\
F-statistic & 32.55499 & Durbin- & 5 \\
& & Watson stat & \\
Prob(F-statistic) & 0.000000 & & \\
\hline
\end{tabular}

Variable:

1. Independent variable $(X)=$ digital banking merger of Islamic banks

2. Dependent variable $(\mathrm{Y})=$ optimization of existing state-owned bank customers

Hypothesis criteria:

1. $\mathrm{Ha}=$ there is a relationship between variable $\mathrm{x}$ and variable $\mathrm{y}$

2. $\mathrm{Ho}=$ there is no relationship between variable $\mathrm{x}$ and variable $\mathrm{y}$

Hypothesis provisions:

1. Ho will be accepted when $t$ count $<t$ table

2. Ha will be accepted when $t$ count $>t$ table

It is known:

$$
\begin{aligned}
\mathrm{t} \text { count } & =5.705698 \\
\mathrm{t} \text { table } & =\mathrm{n}-2=60-2=58 \\
& =2.000(\mathrm{two} \text { tail })
\end{aligned}
$$

Then $t$ count $>t$ table and Ha will be accepted by rejecting Ho. Thus, there is an effect of variable $X$ (digital banking merger of Islamic banks) on variable $Y$ (optimization of existing customers of state-owned banks. The T-test assessment using the $\mathrm{t}$-significant measurement or $\mathrm{p}$ value is as follows:

Hypothesis criteria:

1. $\mathrm{Ha}=$ there is a relationship between the $\mathrm{x}$ variable and the variable $\mathrm{y}$

2. Ho $=$ there is no relationship between variable $\mathrm{x}$ and variable $\mathrm{y}$ Hypothesis provisions:

1. Ha will be accepted when $p$ value $<0.05$

2. H0 will be accepted when $p$ value $>0.05$ 
Assessment using T-significance or $\mathrm{p}$ value also indicates a value $<0.05$ Where according to the provisions and criteria of the T-test, it can be concluded that the results show a positive influence between the $X$ variable (digital banking merger of Islamic banks) on the $\mathrm{Y}$ variable (optimization of existing state-owned bank customers).

\section{Analysis}

Based on the results of the partial hypothesis test that has been carried out by the researcher, the results show that:

1. State-Owned Enterprises Merger Policy

Swot analysis shows quadrant 1 . Thus the stategi done is appropriate or on the track but to maintain competence, the state that is done must be aggressive or growth oriented strategy that according to Astuti and Ratnawati, can be known because it has great opportunities and can maximize the opportunities that are owned. In other words, islamic bank mergers have many opportunities as the top leader of islamic financial growth and development in Indonesia. And as a strategy, Bank Sharia Indonesia must be able to maximize the opportunities it has where one of them is the existence of nsabah who has interest and trust (existing) in stateowned banks, as well as BSI's opportunity as the creator of a competitive Islamic banking market in innovating and serving the community.

2. Digital Islamic Bank Merger In Creating A Healthy Competitive Market The results of the first descriptive analysis showed an index of $36.7 \%$ which means that customers do not agree about the statement that state-owned banks are less desirable because of the presence of private banks that better service. The second result showed an index figure of $72 \%$ which entered the "agree" interval, which means that existing customers of state-owned banks agree if there are new services at state-owned banks they are interested in using their services. In conclusion, that existing customers of state-owned banks are most likely to use the services of Bank Sharia Indonesia which is the result of mergers of state-owned Islamic banks

3. Optimization Of Introduction Of Islamic Bank Products Through Existing Customers Of State-Owned Banks

The test result is $<0.05$. Where according to the provisions and criteria of the T-test, it can be concluded that the results show a positive influence between variable $X$ (digital banking merger of Islamic banks) to variable $\mathrm{Y}$ (optimization of existing customers of state-owned banks).

\section{Conclusion}

The results showed that all the hypotheses formulated were acceptable. Based on the results of basic SWOT research, it can be concluded that the strategy carried out is appropriate or on the track but to maintain competence, the state that is done in the future is an aggressive or growth oriented strategy. And as an 
aggressive strategic support step, Bank Sharia Indonesia can maximize the opportunities it has where one of them is the existence of customers who have a dominant interest and trust (existing) in state-owned banks, as well as the opportunity of BSI as the creator of a competitive Islamic banking market to maximize Islamic banking services in Indonesia.

\section{References}

[1]Alamsyah, Halim. 2012. "Perkembangan Dan Prospek Perbankan Syariah Indonesia: Tantangan Dalam Menyongsong MEA 2015." Milad Ke-8 Ikatan Ahli Ekonomi Islam (IAEI), no. April 2012.

[2]Alexander, Ivan, and Hendrik Johannes Nadapdap. 2019. “Analisis Daya Saing Ekspor Biji Kopi Indonesia Di Pasar Global Tahun 2002-2017." JSEP (Journal of Social and Agricultural Economics) 12 (2). https://doi.org/10.19184/jsep.v12i2.11271.

[3]“Jdih Kemnaker.” n.d. Accessed November 12, 2021. https://jdih.kemnaker.go.id/katalog-237-Peraturan Menteri.html.

[4]Kasmir. 2008. “Bank Dan Lembaga Keuangan Lainnya, Jakarta." Penerbit PT Raga Grafindo Persada. Halaman: 96.

[5]Keuangan, Otoritas Jasa (OJK). 1967. “Statistik Perbankan Syariah Februari 2021." Angewandte Chemie International Edition 6 (11): 951-52.

[6]Kho, Dickson. 2018. "Pengertian Skala Likert Dan Cara Menggunakan Skala Likert.” Teknik Elektronika. 2018.

[7]Ojk.go.id. 2021. “Statistik Perbankan Syariah April 2021," 1-119.

https://www.ojk.go.id/id/kanal/syariah/data-dan-statistik/statistik-perbankansyariah/Documents/Pages/Statistik-Perbankan-Syariah---April-2021/SPS April 2021.pdf.

[8]Santoso, Singgih. 2019. "Mahir Statistik Parametrik." PT Elex Media Komputindo, 60.

[9]Tho' in, Muhammad. 2019. "Profitability of Islamic Commercial Banks In Indonesia." IQTISHADIA: Jurnal Ekonomi \& Perbankan Syariah 6 (2). https://doi.org/10.19105/iqtishadia.v6i2.2429.

[10]Thomson Reuters, Dinar Standard. 2018. "State of the Global Islamic Economy Report 2018/19." Dubai International Financial Centre, 112. https://haladinar.io/hdn/doc/report2018.pdf.

\{11\}Utami, Novia Widya. 2019. “Analisis SWOT: Manfaat, Faktor, Dan Contohnya.” Jurnal Entrepreneur. 